\title{
Putative roles of purinergic signaling in human immunodeficiency virus-1 infection
}

\author{
Paulo AF Pacheco ${ }^{1}$, Robson X Faria ${ }^{1 *}$, Leonardo GB Ferreira ${ }^{1}$ and Izabel CNP Paixão²
}

\begin{abstract}
Nucleotides and nucleosides act as potent extracellular messengers via the activation of the family of cell-surface receptors termed purinergic receptors. These receptors are categorized into P1 and P2 receptors (P2Rs). P2Rs are further classified into two distinct families, P2X receptors (P2XRs) and P2Y receptors (P2YRs). These receptors display broad tissue distribution throughout the body and are involved in several biological events. Immune cells express various P2Rs, and purinergic signaling mechanisms have been shown to play key roles in the regulation of many aspects of immune responses. Researchers have elucidated the involvement of these receptors in the host response to infections. The evidences indicate a dual function of these receptors, depending on the microorganism and the cellular model involved. Three recent reports have examined the relationship between the level of extracellular ATP, the mechanisms underlying purinergic receptors participating in the infection mechanism of HIV-1 in the cell. Although preliminary, these results indicate that purinergic receptors are putative pharmacological targets that should be further explored in future studies.
\end{abstract}

Reviewers: This article was reviewed by Neil S. Greenspan and Rachel Gerstein.

Keywords: P2X7R, HIV-1 infection, Antagonists, Pharmacological targets

\section{Introduction}

Nucleotides and nucleosides are fundamental molecules in cell metabolism that perform a wide range of acknowledged functions that include acting as energy sources and being the structural building blocks of nucleic acids $[1,2]$. Furthermore, these compounds act as potent extracellular signaling molecules and neurotransmitters via the activation of a family of cell-surface receptors termed purinergic receptors [3]. Based on biochemical, pharmacological and molecular biological studies, purinergic receptors are categorized into P1 receptors (for adenosine) and P2 receptors (P2Rs, for ATP/ADP and some pyrimidines) [4-8].

To date, four P1 receptors have been identified: $A_{1}$, $A_{2 A}, A_{2 B}$ and $A_{3}$. All of these molecules are typical $G$ protein-coupled receptors, although they differ with respect to the $G$ protein to which they are coupled $[8,9]$. The P2Rs are separated into two distinct families: the ionotropic P2X receptors (P2XRs) (activated by ATP)

\footnotetext{
* Correspondence: robson.xavier@gmail.com

'Laboratory of Cellular Communication, Oswaldo Cruz Foundation, Av. Brazil, 4365 Rio de Janeiro, Brazil

Full list of author information is available at the end of the article
}

and the metabotropic P2Y receptors (P2YRs) (that bind to ATP, UTP or their metabolites) [10-12]. Mammals express seven subtypes of P2XR monomers (P2X1-7R) and eight subtypes of P2YR monomers (P2Y1R, P2Y2R, P2Y4R, P2Y6R, P2Y11R, P2Y12R, P2Y13R, and P2Y14R) $[13,14]$.

The P2XRs function as ATP-gated ion channels. Following the binding of an agonist to their extracellular portions, they undergo conformational changes that result in the opening of an ion channel, facilitating the influx/efflux of cations [15-17]. Following prolonged activation by ATP, some P2XRs, such as P2X2R, P2X4R and P2X7R, are capable of undergoing an additional conformational change, which increases the permeability of large molecules [18-20]. In response to prolonged exposure to ATP, other P2XRs, such as P2X1R and P2X3R, undergo a fast desensitization, resulting in channel closure [17,21-23]. Functional P2XRs are assembled into either homomeric or heteromeric trimers, each subunit of which contains two transmembrane domains; a large extracellular loop, which includes 10 conserved cysteines and glycosylation sites; and intracellular $\mathrm{N}$ and $\mathrm{C}$ terminal domains, which contain consensus phosphorylation sites for protein 
kinases [5,6,24-26]. The detailed signaling process that is triggered by the activation of most P2XRs has yet to be completely elucidated. For instance, one possible intermediate in the activation of MAPKs, PKC and calmodulin may be the cytoplasmic calcium $[25,27]$.

The P2YR subtypes are typical G protein-coupled receptors (GPCRs), which typically consist of seven transmembrane domains connected by three extracellular and three intracellular loops. The $\mathrm{N}$-terminus is extracellular, and the C-terminus is intracellular [28-30]. Similar to other GPCRs, stimulation of P2YRs induces the activation of a heterotrimeric $\mathrm{G}$ protein and its dissociation into $\alpha$ and $\beta \gamma$ subunits, activating a range of effector proteins, such as phospholipase $\mathrm{C}$ and adenylyl cyclase [25]. The P2YR family displays high diversity with respect to amino-acid composition and structural diversity with respect to the intracellular loops and the $\mathrm{C}$-terminus, influencing the degree of coupling with functionally distinct types of $\mathrm{G}$ proteins [31,32].

P2Rs are broadly distributed throughout nervous, endocrine, cardiovascular, renal, gastrointestinal and immune tissues [33] and participate in several biological events, such as platelet aggregation, exocrine and endocrine secretion, endothelial-mediated vasodilatation, nociceptive mechanosensory transduction, neuromodulation and neuroprotection, cell proliferation, differentiation, migration and death during embryological development, wound healing, epithelial cell turnover and immune responses $[14,16]$.

\section{Review}

Importance of purinergic signaling in immune responses Most immune cells express both $\mathrm{P} 1$ and $\mathrm{P} 2$ receptor subtypes [34-39]. A large body of evidence has demonstrated that extracellular nucleotides and purinergic receptors are key regulators of many immune phenomena, such as inflammatory pain, cytokine secretion, chemotaxis, activation of various types of immune system cells, surface-antigen shedding and pathogen killing.

ATP, adenosine and other nucleotides are also involved in regulating the migratory responses of neutrophils, macrophages and other innate immune cells [40,41]. Metabolic stress, ischemia, hypoxia, inflammation and trauma lead to the accumulation of adenosine in the extracellular space, reporting tissue injury to the surrounding tissue in an autocrine and paracrine manner. Another possibility is that adenosine generates tissue-protective responses [42-44]. In its protective function, adenosine downregulates the expression of adhesion molecules, the production of oxygen radicals, degranulation and the release of cytokines, consequently reducing cellular cytotoxic activities [45-52]. In particular, ATP and UTP that have been released by apoptotic cells act as "find-me signals" that induce phagocyte migration toward these cells [53]. In neutrophils, stimulation with the chemotactic peptide $N$-formyl-Met-Leu-Phe causes a rapid release of ATP in a polarized manner. This released ATP activates P2Y2R to modulate cellular orientation. The adenosine formed via ATP degradation and subsequent stimulation of the $\mathrm{A}_{3}$ receptor enables autocrine signal amplification, which facilitates chemotaxis by regulating the speed of migration [54]. Similar results have been observed in macrophages, in which stimulation with the chemoattractant $\mathrm{C5a}$ induced migration via the release of ATP and the activities of the autocrine purinergic signaling system [55]. In addition, some studies have suggested that ATP acts as a signal that induces the release of chemotactic factors [56]. In contrast, other studies have found evidence that nucleotides themselves function as chemotactic signals $[53,57,58]$. Extracellular nucleotides are also involved in modulating lymphocyte responses. B cells express various P2R subtypes [38,59] and are able to release ATP under steady-state conditions [60]. Incubating human B cells with increased ATP concentration triggers a dose-dependent increase in the level of inositol 1,4,5trisphosphate as well as an increase in the level of cytosolic free $\mathrm{Ca}^{2+}$. In addition, the c-fos and c-myc mRNA levels increase, indicating that P2-receptor stimulation was associated with this activity [61]. A transfection study using two P2X7R non-expressing human lymphoid cell lines (K562 and LG14 cells) showed that the heterologous expression of this receptor enhanced cell proliferation in the absence of growth factors and was dependent on the level of released ATP [62].

Similarly, several stages of the life of a $\mathrm{T}$ lymphocyte may be affected by purinergic signaling, including differentiation, activation and proliferation. Thymocytes are susceptible to apoptosis in the presence of extracellular ATP via the activation of purinergic receptors in vitro and in vivo [63-69]. The sensitivity of this cell type to extracellular ATP is closely associated with its degree of maturation, highlighting the importance of the purinergic system in the regulation of cellular differentiation in the thymus [70]. Recently, signaling via purinergic receptors has been associated with fate determination during T-cell development. P2X7R activation contributes to the strength of the $\gamma \delta$ TCR signal in immature thymocytes. The genetic ablation or pharmacological inhibition of this receptor directs cells toward the $\alpha \beta$ fate [71]. Peripheral T lymphocytes release ATP into the extracellular milieu under several conditions, such as TCR stimulation, mechanical stimulation or osmotic stress [72-76], via either the pannexin 1 hemichannel $[77,78]$ or vesicular exocytosis [79]. In these cells, the binding of extracellular ATP to P2Rs modulates several steps required for complete T-cell activation, such as the influx of extracellular calcium, the activation of p38 MAPK and the secretion of IL-2 [72,75,80-82]. In addition to conventional $\alpha \beta$ T lymphocytes, the activation state of $\gamma \delta \mathrm{T}$ cells is also regulated by ATP release and autocrine signaling 
via a purinergic receptor, namely P2X4R [83]. Similarly, activation of P2X7R by ATP inhibits the suppressive function and disrupts the gene transcription profile of Tregs and promotes the differentiation of these cells into proinflammatory TH17 effector cells [84].

Furthermore, purinergic signaling, particularly that involving P2X7R, also acts as a potent mediator of the release of proinflammatory cytokines. One of the best studied examples of this correlation is the participation of P2X7R in the processing and release of IL-1 $\beta$ and IL18 $[85,86]$. Based on experiments performed in vitro and in vivo using $\mathrm{P} 2 \mathrm{X} 7^{-1-}$ mice, ATP was identified as a strong IL-1 $\beta$-releasing agent that acts via this receptor. LPS, the strongest inducer of IL-1 secretion, is an incomplete stimulus in the absence of ATP, leading to the accumulation of pro-Il- $1 \beta$ in cytoplasmic vesicles [85,87].

These findings reinforce the importance of purinergic signaling mechanisms as key regulators of many aspects of immune responses. Under normal conditions, extracellular ATP (the natural agonist of most P2Rs) is present at nanomolar concentrations, which are maintained by extracellular nucleotide-hydrolyzing enzymes, such as ecto-nucleoside triphosphate diphosphohydrolases (E-NTPDases) [88-90]. However, under certain conditions, such as inflammatory, ischemic and hypoxic states, several different cell types release ATP from intracellular storage compartments into the extracellular media, elevating its external concentration to the millimolar range and inducing predominantly proinflammatory responses [90,91]. Several mechanisms for ATP release have been described, including cell death, vesicular transport, and the activities of stretch-activated channels, volume-regulated channels, maxi-anion channels, pannexin and connexin hemichannels and P2X7R [9,13,92]. In a "stressful environment" containing damaged host cells and the leakage of intracellular contents, purinergic receptors allow immune cells to recognize the ATP that is released into the extracellular milieu. Therefore, purinergic signaling participates in an important system that recognizes "danger" signals, alerting the immune system to a threat $[93,94]$. Accordingly, the damage caused by pathogens at the infection site induces the release of additional ATP [95].

In this regard, it appears that a natural consequence of stress conditions is the alteration of purinergic signaling, which may be related to pathological processes associated with infectious conditions.

\section{Involvement of purinergic receptors in HIV infection}

Accordingly, some studies have investigated the involvement of purinergic receptors, particularly P2X7R, in infectious processes [96], as shown in Table 1.

Several studies have reported the involvement of purinergic receptors in viral infections, either as facilitators or as host defense factors. Purinergic receptor antagonists, such as suramin, pyridoxal-phosphate-6-azophenyl-2',4'-disulfonate (PPADS) and brilliant blue G (BBG), the latter of which is a selective blocker of P2X7R, have been used to block the infection of hepatocytes by the hepatitis B virus [120-122]. Suramin has been demonstrated to exert antiviral effects on other animal viruses $[123,124]$, although no further studies have associated the antagonistic action of this compound with purinergic receptors. Moreover, human endothelial cells infected in vitro with cytomegalovirus displayed significantly increased expression of P2Y1R, P2Y2R and P2X7R compared to uninfected cells, although only slight effects were found following infection with the herpes virus, likely indicating a virus-specific effect [125].

Despite all of the efforts to control and prevent the spread of human immunodeficiency virus (HIV) type 1 (HIV-1), HIV-1 infection and the resulting acquired immunodeficiency syndrome (AIDS) remain public health problems worldwide. HIV is an enveloped virus classified into a subgroup of retroviruses termed lentiviridae because these viruses exhibit extended clinical latency and persistent viral replication throughout the illness [126-130]. The continuous replication of HIV-1 and chronic immune activation mediate the drastic depletion of CD4+ T cells, a hallmark of infection with HIV-1 and other associated immune disorders [131-134]. Throughout the course of infection, immune responses only partially control the level of these viruses in the blood [135].

The emergence of highly active antiretroviral therapy (HAART) has enabled significant improvements in the management of HIV-infected patients: the reduction of plasma HIV-1 levels below the level of detection of commercially available tests and limited immune reconstitution [136-139]. The use of HAART has resulted in a significant reduction in AIDS-related morbidity and mortality [140]. However, although HAART efficiently delays the onset of AIDS, its clinical utility is limited by several barriers, such as viral resistance, non-adherence to therapy and drug toxicity. Therefore, the search for new targets of HIV-1 and/or host cellular proteins is essential for the success of HIV-1 treatment [141-143].

Three recent reports have directly assessed the possible involvement of purinergic receptors in the immunopathogenesis of HIV-1 infection, raising the possibility of using these host proteins as targets for HIV-1 treatment. Séror et al. found that infecting human cells with HIV-1 leads to the release of ATP via pannexin-1 hemichannels and that this event is essential for the initial infection. The ATP-degrading enzyme apyrase prevents HIV-1 infection. Similarly, pharmacological inhibition of pannexin-1 hemichannels or depletion of this protein using small interfering RNAs protected the targeted cells from HIV-1-mediated cell death and prevented HIV-1 infection. 
Table 1 Involvement of purinergic in infectious processes

\begin{tabular}{|c|c|c|c|c|}
\hline Microorganism & Receptor & Cell type & Involvement & Reference \\
\hline \multicolumn{5}{|l|}{ Bacteria } \\
\hline M. tuberculosis & ND & monocyte & $\begin{array}{l}\text { ATP induced apoptosis of infected monocyte and reduced } \\
\text { viability of intracellular bacilli }\end{array}$ & {$[97]$} \\
\hline $\mathrm{BCG}$ & $\mathrm{P} 2 \times 7$ & Human macrophage & $\begin{array}{l}\text { Treatment with exogenous ATP caused cell death and } \\
\text { killing of intracellular mycobacteria within BCG infected } \\
\text { macrophages }\end{array}$ & {$[98]$} \\
\hline M. tuberculosis & $\mathrm{P} 2 \times 7$ & Human macrophage & $\begin{array}{l}\text { Treatment with ATP reduced viability of three virulent } \\
\text { strains of mycobacteria within human macrophages, what } \\
\text { was associated with stimulation of phospholipase D } \\
\text { activity }\end{array}$ & {$[99]$} \\
\hline $\mathrm{BCG}$ & $\begin{array}{l}\mathrm{P} 2 \mathrm{X} 7 \text { and } \\
\mathrm{P} 2 \mathrm{Y}\end{array}$ & Human macrophage & Apoptosis of infected cells and killing of intracellular bacilli & {$[100]$} \\
\hline M.bovis & $\mathrm{P} 2 \mathrm{X} 7$ & Bovine macrophage & $\begin{array}{l}\text { ATP induced killing Mycobacterium bovis in bovine } \\
\text { macrophages in a mechanism P2X7R-dependent }\end{array}$ & {$[101]$} \\
\hline BCG & $\mathrm{P} 2 \times 7$ & $\begin{array}{l}\text { Murine bone-marrow derived macrophages } \\
\text { and murine macrophage cell line }\end{array}$ & $\begin{array}{l}\text { P2X7R stimulation with ATP induced rapid fusion of } \\
\text { BCG-containing phagosomes with lysosomes, resulting in } \\
\text { formation of multibacillary vacuoles. Also, P2X7R resulted } \\
\text { in progressive acidification of BCG-containing phagosomes } \\
\text { in infected macrophages }\end{array}$ & {$[102]$} \\
\hline $\mathrm{BCG}$ & $P 2 \times 7$ & Human macrophage & $\begin{array}{l}\text { Loss-of-function polymorphism } 1513 \mathrm{~A} \rightarrow \mathrm{C} \text { abolished } \\
\text { apoptosis of infected macrophages and mycobacterial } \\
\text { killing }\end{array}$ & {$[103]$} \\
\hline $\mathrm{BCG}$ & $\mathrm{P} 2 \mathrm{X7}$ & Human macrophage & $\begin{array}{l}\text { The } 1513 \mathrm{C} \text { allele was associated to increased susceptibility } \\
\text { to extracellular TB and ATP-mediated killing of } \\
\text { mycobacteria in macrophages was absent in homozygous } \\
\text { subjects and impaired in heterozygous subjects }\end{array}$ & {$[104]$} \\
\hline $\mathrm{BCG}$ & $P 2 \times 7$ & Human macrophage & $\begin{array}{l}\text { Loss-of-function polymorphism } 1096 \mathrm{C} \rightarrow \mathrm{G} \text { (change Thr } \\
\text { (357) to Ser (T357S)) associated to reduced or near to } \\
\text { absent ATP-induced killing of intracellular mycobacteria }\end{array}$ & {$[105]$} \\
\hline M. tuberculosis & $\mathrm{P} 2 \times 7$ & Human PBMC & $\begin{array}{l}\text { PBMC from TB patients presented different pattern of } \\
\text { gene expression in response to ATP when compared to } \\
\text { healthy contacts }\end{array}$ & {$[106]$} \\
\hline M. tuberculosis & $\mathrm{P} 2 \times 7$ & Human monocyte/macrophages & $\begin{array}{l}\text { Mycobacterial infection induced an increase of P2X7 } \\
\text { expression, higher release of ATP and an increment of } \\
\text { intracellular ATP accumulation }\end{array}$ & {$[107]$} \\
\hline $\mathrm{BCG}$ & $P 2 \times 7$ & THP-1 and monocyte-derived macrophage & $\begin{array}{l}\text { ATP treatment activated autophagy pathway via a } \\
\text { Ca2 + - dependent process. This effect was associated } \\
\text { with a phago-lysosomal fusion and of mycobacteria- } \\
\text { containing phagosomes, resulting in reduction in } \\
\text { intracellular BCG viability }\end{array}$ & {$[108]$} \\
\hline C. psittaci & $\mathrm{P} 2 \times 7$ & Murine macrophage cell line & $\begin{array}{l}\text { ATP but no other nucleotides was able to induce } \\
\text { reduction in viability of intracellular bacteria and } \\
\text { chlamydial infection prevented ATP-mediated apoptosis }\end{array}$ & {$[109]$} \\
\hline C. trachomatis & $P 2 \times 7$ & $\begin{array}{l}\text { Murine peritoneal macrophage cells and } \\
\text { macrophage cell line }\end{array}$ & $\begin{array}{l}\text { Chlamydial killing upon ATP treatment of infected cells } \\
\text { required phospholipase D activation, which is mediated by } \\
\text { P2X7R stimulation that leads to lysosome fusion with } \\
\text { mature Chlamydia vacuoles }\end{array}$ & {$[110]$} \\
\hline C. muridarum, & P2X7 & Human cervical adenocarcinoma cell line & $\begin{array}{l}\text { Extracellular ATP or other P2X7R agonists induced a } \\
\text { decrease in chlamydial viability in epithelial cells, which } \\
\text { was dependent on phospholipase D activity and blocked } \\
\text { by treatment with P2X7R antagonists and butan-1-ol } \\
\text { (PLD inhibitor). Also, vaginal infection was more efficient in } \\
\text { P2X7R-deficient mice, what was correlated to higher level } \\
\text { of acute inflammation }\end{array}$ & [111] \\
\hline
\end{tabular}

\section{Protozoan}




\section{Table 1 Involvement of purinergic in infectious processes (Continued)}

\begin{tabular}{|c|c|c|c|c|}
\hline L. amazonensis & $\mathrm{P} 2 \times 7$ & Murine peritoneal macrophage & $\begin{array}{l}\text { Leishmania infection leads to increased expression of } \\
\text { P2X7R and higher responsiveness to ATP treatment. Also, } \\
\text { incubation with ATP reduced the parasite load, which was } \\
\text { reverted by pre-treatment with oxidized ATP and was not } \\
\text { not dependent of cell lysis or NO production }\end{array}$ & [113] \\
\hline L. amazonensis & $\mathrm{P} 2 \times 7$ & Murine peritoneal macrophage & $\begin{array}{l}\text { Macrophages infected with L. amazonensis exhibit higher } \\
\text { apoptosis rate and parasite degradation upon ATP } \\
\text { treatment and presented differential modulation of the } \\
\text { uptake of cationic and anionic dyes }\end{array}$ & {$[114]$} \\
\hline L. amazonensis & $\mathrm{P} 2 \mathrm{Y}$ & Murine peritoneal macrophage & $\begin{array}{l}\text { Uridine nucleotides reduced parasite load and induced } \\
\text { morphological damage of intracellular parasites and } \\
\text { infected cells. They also induced significant levels of } \\
\text { apoptosis, ROI and RNI in infected cells. }\end{array}$ & {$[115]$} \\
\hline T. gondii & $\mathrm{P} 2 \times 7$ & $\begin{array}{l}\text { Murine peritoneal cell and macrophage } \\
\text { cell line }\end{array}$ & $\begin{array}{l}\text { ATP or BzATP treatment reduced parasite load. Parasite } \\
\text { load was not reduced in P2X7R-deficient mouse. } \\
\text { Furthermore, ATP treatment caused ultrastructural changes } \\
\text { in tachyzoite inside macrophages, increased lysosome } \\
\text { fusion with parasitophorous vacuole and ROS production }\end{array}$ & [116] \\
\hline T. gondii & $P 2 \times 7$ & $\begin{array}{l}\text { Human macrophage and murine bone } \\
\text { marrow-derived macrophage and } \\
\text { macrophage-like cell line }\end{array}$ & $\begin{array}{l}\text { Infected macrophages obtained from homozygous } \\
\text { individuals for loss-of-function polymorphism } 1513 \mathrm{~A} \rightarrow \mathrm{C} \\
\text { had no significant alteration in parasite load after ATP } \\
\text { treatment. Similarly, macrophages from P2X7R knockout } \\
\text { mice were not able to kill T. gondii upon ATP treatment }\end{array}$ & {$[117]$} \\
\hline T. gondii & $P 2 \times 7$ & Human Peripheral blood cells & $\begin{array}{l}\text { SNP } 1068 \mathrm{~T} \rightarrow C \text { was found positively associated with } \\
\text { resistance to both congenital and ocular toxoplasmosis }\end{array}$ & [118] \\
\hline T. gondii & $P 2 \times 7$ & Murine peritoneal cell & $\begin{array}{l}\text { In vivo infection of P2X7-deficient mouse resulted in a } \\
\text { more severe acute infection, higher parasite burdens and } \\
\text { pronounced liver pathology }\end{array}$ & [119] \\
\hline
\end{tabular}

General inhibitors of purinergic receptors blocked the replication of X4-tropic and R5-tropic HIV in activated T lymphoblasts and that of R5-tropic HIV in macrophages and dendritic cells. The selective depletion of mRNAs encoding diverse purinergic receptors using interfering RNAs facilitated the identification of P2Y2R as a receptor related to HIV infection. Immunohistochemistry has revealed elevated levels of P2Y2R in lymphoid tissue, the frontal cortex and circulating leukocytes in untreated carrier patients compared with uninfected patients. Immunofluorescence microscopy has shown that P2Y2R is polarized at the virological synapse. Pharmacological inhibition or genetic ablation of P2Y2R has reproduced the effects of general purinergic receptor blockers. Ultimately, proline-rich tyrosine kinase 2 (Pyk2), a downstream effector of P2Y2R, was found to be a critical mediator of HIV-1 infection [144].

The second study demonstrated that inhibiting the purinergic receptors of macrophages resulted in a significant reduction in the rate of HIV replication. Macrophages are indispensable in HIV pathogenesis because they are susceptible to productive infection, often in the absence of cytopathic or deleterious effects, thus serving as long-lived virus reservoirs $[145,146]$. Therefore, improving the understanding of the mechanisms by which HIV infects and replicates within macrophages is crucial for designing appropriate strategies to reduce the latency and spread of HIV-1 [147]. Using oxidized ATP, a P2XR antagonist, Hazleton et al. detected significant inhibition of HIV replication in macrophages in a dose-dependent and viral strain-independent manner, indicating that purinergic receptors may be required for HIV replication. To further discriminate which P2Rs may be involved, macrophages were treated with specific pharmacological P2R antagonists. This approach revealed the requirement of at least three purinergic receptors, P2X1R, P2X7R and P2Y1R. Moreover, using a $\beta$-lactamase HIV entry assay, P2X1R was demonstrated to participate in the viral entry of macrophages. Finally, treating primary cultures of human macrophages with HIV gp120 resulted in significantly increased release of ATP, indicating the possible autocrine regulation of critical events in the viral life cycle [148].

In the third study, P2XR antagonists inhibited HIV-1 from infecting CD4+ T lymphocytes via both cell-free and cell-to-cell contact in a dose-dependent manner. Additionally, exploration of a library of purinergic antagonists demonstrated that P2XR antagonists are the most potent inhibitors of HIV-1 fusion, providing evidence of a new therapeutic target to prevent HIV-1 infection of CD4+ T lymphocytes [149].

Purinergic receptors have also been associated with the neurotoxicity caused by HIV in infected individuals. In the central nervous system, microglia are activated by HIV-1, and in response, these cells release neuroinflammatory 
and excitotoxic products that are associated with the pathogenesis of neuroAIDS in many infected individuals [150]. Because P2XRs are key regulators of microglial functions, Sorrel and Hauser investigated whether these receptors are involved in the neurotoxic effects of HIV and morphine in infected individuals, as it has been reported that opioid-dependent microglial activation is mediated by P2X4R signaling. Pretreatment of microglia with TNP-ATP, a nonselective stimulator of P2XRs, inhibited Tat- and/or morphine-related neuronal death in a dosedependent manner and prevented the increase in cytosolic free $\mathrm{Ca}^{2+}$. They also detected a rise in the level of ATP in the medium of neuron-glia co-cultures after 30 minutes of incubation in Tat and morphine, either individually or in combination. Finally, using P2XR antagonists and agonists, P2X4R was identified as the receptor responsible for neurotoxicity in HIV-infected individuals [151]. Similarly, large amounts of ATP, ADP and AMP and small amounts of adenosine and glutamate were detected in the supernatant of HIV-infected macrophage cultures. Applying diluted aliquots of these supernatants to neuronal cultures increased the amount of extracellular glutamate and decreased the neuronal spine density via mechanisms that are dependent on purinergic and glutamatergic receptor activation [150].

Previous investigations have also explored the role of adenosine receptors in the pathogenesis of AIDS. Pingle et al. demonstrated a protective effect of stimulating the A1A receptor $\left(\mathrm{A}_{1 \mathrm{~A}} \mathrm{R}\right)$ against HIV-1 Tat-induced toxicity in primary cultures of rat cerebellar granule neurons and in rat pheochromocytoma (PC12) cells. Activation of $\mathrm{A}_{1 \mathrm{~A}} \mathrm{R}$ ameliorated the Tat-mediated changes in $\mathrm{PC} 12$ cells, such as the increase in the intracellular $\mathrm{Ca}^{2+}$ content, the release of $\mathrm{NO}$ and the expression of inducible nitric oxide synthase (iNOS). Furthermore, pretreatment with an $\mathrm{A}_{1 \mathrm{~A}} \mathrm{R}$ agonist reduced the level of activation of NF- $\kappa B$ by Tat and the number of apoptotic cells [152]. Moreover, $\mathrm{A}_{2 \mathrm{~A}} \mathrm{R}$ stimulation inhibited the Tat-induced production of TNF- $\alpha$, a cytokine that plays a pathological role in HIV-associated dementia, by macrophages [153]. Together, these studies suggest that modulating the activity of the adenosine receptor may be helpful in preventing HIV-1-associated abnormalities [154]. Furthermore, another report showed that stimulating the A2A receptor using a monoclonal antibody reduced the level of expression of the chemokine receptors CXCR4 and CCR5 in CEM T-cells, indicating a putative mechanism that could be exploited to block the entry of HIV-1 [155].

\section{Conclusion}

Purinergic receptors are considered to be powerful modulators of several physiological and pathological events, making them attractive molecular targets for pharmacological research. Although great advances in the management of $\mathrm{HIV}$-infected patients have been achieved due to the emergence of HAART, barriers such as drug resistance, drug toxicity and the cost of treatment necessitate the development of new antivirals [156]. Accordingly, recent reports of the role of purinergic receptors in the immunopathogenesis of HIV-1 infection indicate that they are putative pharmacological targets that should be further explored. In addition, ATP could strengthen the function of the innate and adaptive immune systems because it modulates immunological events that are crucial for the anti-HIV response. For instance, prostaglandin E2 (PGE2) inhibited HIV-1 replication in macrophages via a protein kinase A-dependent mechanism [157]. Interestingly, P2X7R stimulation by ATP is required for the release of PGE2 and other autacoids [158]. Additionally, Leal and colleagues found a significant increase in the expression level of CD39 (NTPDase-1) in lymphocytes from HIV-patients, which correlated to a significant increase in the ATP- and ADP-hydrolytic activities [159]. These findings indicate that extracellular nucleotides might be closely associated with the immune response to HIV infection.

Therefore, further studies must be conducted to improve the understanding of the extent and impact of purinergic signaling activities during all stages of HIV-1 infection.

\section{First round}

\section{Reviewer's report}

Reviewer 1: Neil S. Greenspan, Case Western Reserve University, United States of America

\section{Reviewers' comments}

Pacheco et al. review several aspects of purinergic signaling including the receptors and ligands and their roles in immune responses, bacterial infections, protozoal infections, and HIV infection. A quick survey on PubMed of recent reviews on purinergic signaling reveals none focused precisely on the roles of purinergic ligands and receptors in HIV infection. Thus, the role of purinergic signaling in HIV infection is a topic deserving of review.

The sections on the effects of purinergic signaling in the context of either bacterial or protozoal infections are too brief to be of much use and distract from the main focus on the connections between purinergic signaling and HIV pathogenesis. Similarly, at the beginning of the section pertaining to HIV infection, mentions of effects of purinergic receptor antagonists on infection by "hepatitis virus" (which one, A?, B?, C?, D?) or the effects of cytomegalovirus on expression of purinergic receptors seem gratuitous and can be deleted. 
Answer 1: We did the alterations recommended and focused the text in the HIV-1.

The focus needs to be more specifically on how purinergic ligands and receptors participate in HIV pathogenesis. Greater integration of the material addressing effects of purinergic molecules on immune responses in general and on HIV infection in particular would strengthen the article. The authors would also add value to their review by identifying specific experimental questions deserving further exploration.

Answer 2: We did the alterations recommended.

Quality of written English: Not suitable for publication unless extensively edited.

Answer 3: We sent the paper to American Journal Experts. The certificate is attached.

\section{Reviewer's report}

Reviewer 2: Rachel Gerstein, University of Massachusetts Medical School, United States of America

Report form:

Overall, this review needs considerable revision to be more effective and readable.

Some specific comments that might guide the revision -

Abstract: An abstract should stand alone, and not require specialized knowledge to be understood by the reading audience. And most important, it must give a good idea of what the article is about. To state that there is a "relationship between [...] purinergic signaling [...] and immunopathogenesis of HIV-1" is very vague.

Answer 1: We did the alterations recommended.

Intro and body of review:

1. Is purinergic signaling important in immune **responses $^{* *}$ ? is ATP a DAMP for mature functional immune cells? I was not convinced.

Answer 2: We did the alterations recommended.

3. The section on thymocytes does not seem relevant to a discussion of response to a virus.

Answer 3: In the process of HIV-1 infection, one of the consequences is the reduction of the timopoiesis. The maturation and differentiation of thymocytes are modulated by IL-7 / IL-7 receptor (IL-7R) signaling pathway. During infection by HIV-1 occurs reduction in the level of IL-7 (Young and Angel, 2011).

Young $C D^{1}$, Angel JB. HIV infection of thymocytes inhibits IL-7 activity without altering CD127 expression. Retrovirology. 2011 Sep 16;8:72. doi: 10.1186/1742-4690$8-72$.
4. The mention of TH17 profile, the context (ie "this condition") is unclear.

Answer 4: We changed this in the text.

5. If the authors want to highlight work most related to HIV-1, the inclusion of the sections on bacterial and protozoan infections are not needed.

Answer 5: We changed this in the text.

6. In the last part of section 4, in the "neuroAIDS" section, citations are needed to document the connection and data indicating that ATP levels rise in the brain and that this is tied to cognitive impairment.

Answer 5: We added the reference below in the text.

Luis B. Tovar-y-Romo E Dennis L. Kolson E Veera Venkata Ratnam Bandaru E Julia L. Drewes E David R. Graham \& Norman J. Haughey. Adenosine Triphosphate Released from HIV-Infected Macrophages Regulates Glutamatergic Tone and Dendritic Spine Density on Neurons. J Neuroimmune Pharmacol. DOI 10.1007/s11481013-9471-7.

7. Recent papers should be mentioned:

PMID:24842759, PMID:24158495 and especially: Idzko M, Ferrari D, Eltzschig HK., Nature. 2014 May 15;509 (7500):310-7. doi: 10.1038/nature13085. PMID:24828189

Answer 6: We commented and added the reference above in the text.

Quality of written English: Not suitable for publication unless extensively edited.

Answer 7: We sent the paper to American Journal Experts. The certificate is attached.

\section{Second round}

\section{Reviewer's report}

Reviewer 1: Neil S. Greenspan, CaseWestern Reserve

University, United States of America

Comments to Authors:

Pacheco et al. have responded substantively to the previous reviews by tightening the focus of the manuscript to emphasize the role of purinergic receptors in the pathogenesis of HIV-1 infection of humans. The writing has also been substantially improved, although there are still a small number of passages requiring revision. The following comments note areas of the text requiring author responses.

1. In the abstract, the last two sentences are in need of editing.

"Three recent reports have examined the relationship between the level of extracellular ATP, the mechanisms underlying purinergic receptors participating of in the 
infection mechanism of HIV-1 in the cell. Although preliminary, these results indicate that purinergic receptors are putative pharmacological targets to that should be further explored in future studies."

2. The second-to-last sentence at the end of the first paragraph continuing onto the top of page 4 appears to make more sense if "Although" and "it" are deleted. "Although The detailed signaling process that is triggered by the activation of most P2XRs, it has yet to be completely elucidated."

3. On the top of page 5, in the sentence beginning "A large body of evidence ...," the word "responses" might better be replaced by "phenomena," as immune "responses" are most typically referred to by immunologists to indicate specifically coordinated events involving the proliferation and differentiation of lymphocytes and not separately for every sort of molecular or cellular mechanism that arises in the course of an immune response.

4. The mediator adenosine is referred to as a "danger" molecule. While I recognize that this usage is widespread, I would advise not using it especially when, as here, "danger" is not defined. Frequently, molecules that are taken to correspond to "danger signals," with minimal to no justification are in fact, in some circumstances, causes of danger. For example, I just saw a report that the massive tissue damage that characterizes Ebola virus infection is largely attributable not to direct virus-mediated effects but to the host response, in particular so-called cytokine storm (http://www.npr.org/blogs/goatsandsoda/2014/ 08/26/342451672/howebola-kills-you-its-not-the-virus) from my perspective, calling the release of adenosine a danger signal adds no insight not gleaned from a careful delineation of the effects of adenosine on various receptors and signaling pathways and can easily lead to incorrect conclusions and sloppy thinking.

5. On page 9, in the first full paragraph, it is stated that about HIV-1 infection that: "viruses in the blood, which remains measurable throughout the course of infection ..." The next paragraph seemingly contradicts that assertion ("...the reduction of plasma HIV-1 levels below the level of detection of commercially available tests and limited immune reconstitution (139-142).").

6. On page 13, I would add one word to the sentence quoted below, "Accordingly, recent reports of the role of purinergic receptors in the immunopathogenesis of HIV-1 infection indicate that they are putative pharmacological targets that should be further explored".

Quality of written English: Acceptable

\section{Authors' response}

We accept all of the reviewer's suggestions. The text has been changed to accommodate them.

\section{Reviewer's report by Rachel Gerstein}

University of Massachusetts Medical School, United States of America.

This reviewer provided no comments for publication.

\section{Competing interests}

The authors declare that they have no competing interests.

\section{Authors' contributions}

PAFP wrote the main body of the review and LGBF reviewed and formatted the structure of the text. RXF has reviewed the topics about purinergic receptor and ICNPP has reviewed topics related to HIV-1 infection. All authors read and approved the final manuscript.

\section{Acknowledgements}

The National Counsel of Technological and Scientific Development (CNPq), Foundation for Research Support of the State of Rio de Janeiro (Faperj) and Oswaldo Cruz Institute supported this work.

\section{Author details}

${ }^{1}$ Laboratory of Cellular Communication, Oswaldo Cruz Foundation, Av. Brazil, 4365 Rio de Janeiro, Brazil. 'Laboratory of Molecular Virology (Center for Bioproducts), Universidade Federal Fluminense, Rua Outeiro de São João Batista, s/n, Campus do Valonguinho, Niterói, Rio de Janeiro, Brazil.

Received: 14 May 2014 Accepted: 9 October 2014

Published: 29 October 2014

\section{References}

1. Dubyak GR: Signal transduction by P2-purinergic receptors for extracellular ATP. Am J Respir Cell Mol Biol 1991, 4(4):295-300.

2. Burnstock $G$, Williams M: P2 purinergic receptors: modulation of cell function and therapeutic potential. J Pharmacol Exp Ther 2000, 295(3):862-869.

3. Burnstock $\mathrm{G}$ : A basis for distinguishing two types of purinergic receptor. In Cell Membrane Receptors for Drugs and Hormones: A Multidisciplinary Approach. Edited by Straub RW, Bolis L. New York: Raven; 1978:107-118.

4. Ralevic $V$, Burnstock G: Receptors for purines and pyrimidines. Pharmacol Rev 1998, 50(3):413-492.

5. Surprenant A, North RA: Signaling at purinergic P2X receptors. Annu Rev Physiol 2009, 71:333-359.

6. Burnstock G, Fredholm BB, North RA, Verkhratsky A: The birth and postnatal development of purinergic signalling. Acta Physiol (Oxf) 2010, 199(2):93-147.

7. Fredholm BB, Abbracchio MP, Burnstock G, Daly JW, Harden TK, Jacobson KA, Leff P, Williams M: Nomenclature and classification of purinoceptors. Pharmacol Rev 1994, 46(2):143-156.

8. Fredholm BB, IJzerman AP, Jacobson KA, Linden J, Muller CE: International Union of Basic and Clinical Pharmacology. LXXXI. Nomenclature and classification of adenosine receptors-an update. Pharmacol Rev 2011, 63(1):1-34.

9. Junger WG: Immune cell regulation by autocrine purinergic signalling Nat Rev Immunol 2011, 11(3):201-212.

10. Burnstock $G$, Kennedy $C$ : Is there a basis for distinguishing two types of P2-purinoceptor? Gen Pharmacol 1985, 16(5):433-440.

11. Abbracchio MP, Burnstock G: Purinoceptors: are there families of P2X and P2Y purinoceptors? Pharmacol Ther 1994, 64(3):445-475.

12. Jacobson KA, Boeynaems JM: P2Y nucleotide receptors: promise of therapeutic applications. Drug Discov Today 2010, 15(13-14):570-578.

13. Rayah A, Kanellopoulos JM, Di Virgilio F: P2 receptors and immunity. Microbes and Infection/Institut Pasteur 2012, 14(14):1254-1262.

14. Burnstock G: Purinergic signalling: Its unpopular beginning, its acceptance and its exciting future. Bioessays 2012, 34(3):218-225.

15. Khakh BS: Molecular physiology of $\mathrm{P} 2 \mathrm{X}$ receptors and ATP signalling at synapses. Nat Rev Neurosci 2001, 2(3):165-174.

16. North RA: Molecular physiology of P2X receptors. Physiol Rev 2002 82(4):1013-1067.

17. Jarvis MF, Khakh BS: ATP-gated P2X cation-channels. Neuropharmacology 2009, 56(1):208-215.

18. Khakh BS, Bao XR, Labarca C, Lester HA: Neuronal P2X transmitter-gated cation channels change their ion selectivity in seconds. Nat NeurosCi 1999, 2(4):322-330. 
19. Virginio C, Mackenzie A, Rassendren FA, North RA, Surprenant A: Pore dilation of neuronal P2X receptor channels. Nat Neurosci 1999, 2(4):315-321.

20. Khakh BS, Lester HA: Dynamic selectivity filters in ion channels. Neuron 1999, 23(4):653-658

21. Rettinger J, Schmalzing G: Activation and desensitization of the recombinant P2X1 receptor at nanomolar ATP concentrations. J Gen Physiol 2003, 121(5):451-461.

22. Pratt EB, Brink TS, Bergson P, Voigt MM, Cook SP: Use-dependent inhibition of P2X3 receptors by nanomolar agonist. J Neurosci 2005, 25(32):7359-7365

23. Sokolova E, Skorinkin A, Moiseev I, Agrachev A, Nistri A, Giniatullin R: Experimental and modeling studies of desensitization of $\mathrm{P} 2 \mathrm{X} 3$ receptors. Mol Pharmacol 2006, 70(1):373-382.

24. Nicke A, Baumert HG, Rettinger J, Eichele A, Lambrecht G, Mutschler $E_{\text {, }}$ Schmalzing G: P2X1 and P2X3 receptors form stable trimers: a novel structural motif of ligand-gated ion channels. EMBO J 1998, 17(11):3016-3028

25. Erb L, Liao Z, Seye Cl, Weisman GA: P2 receptors: intracellular signaling Pflugers Arch 2006, 452(5):552-562.

26. Coddou C, Yan Z, Obsil T, Huidobro-Toro JP, Stojilkovic SS: Activation and regulation of purinergic P2X receptor channels. Pharmacol Rev 2011 63(3):641-683.

27. Faria RX, de Farias FP, Alves LA: Are second messengers crucial for opening the pore associated with $\mathrm{P} 2 \mathrm{X} 7$ receptor? Am J Physiol Cell Physiol 2005, 288(2):C260-C271.

28. Boarder MR, Weisman GA, Turner JT, Wilkinson GF: G protein-coupled P2 purinoceptors: from molecular biology to functional responses. Trends Pharmacol Sci 1995, 16(4):133-139.

29. Barnard EA: The transmitter-gated channels: a range of receptor types and structures. Trends Pharmacol Sci 1996, 17(9):305-309.

30. von Kügelgen I, Wetter A: Molecular pharmacology of P2Y-receptors. Naunyn Schmiedebergs Arch Pharmacol 2000, 362(4-5):310-323.

31. von Kügelgen I: Pharmacological profiles of cloned mammalian P2Y-receptor subtypes. Pharmacol Ther 2006, 110(3):415-432

32. Burnstock G: Purine and pyrimidine receptors. Cell Mol Life Sci 2007 64(12):1471-1483.

33. Burnstock G, Knight GE: Cellular distribution and functions of P2 receptor subtypes in different systems. Int Rev Cytol 2004, 240:31-304.

34. Nihei OK, de Carvalho AC, Savino W, Alves LA: Pharmacologic properties of $\mathrm{P}(2 \mathrm{Z}) / \mathrm{P} 2 \mathrm{X}(7)$ receptor characterized in murine dendritic cells: role on the induction of apoptosis. Blood 2000, 96(3):996-1005.

35. Ferrari D, Idzko M, Dichmann S, Purlis D, Virchow C, Norgauer J, Chiozzi P, Di Virgilio F, Luttmann W: P2 purinergic receptors of human eosinophils: characterization and coupling to oxygen radical production. FEBS Lett 2000, 486(3):217-224.

36. Di Virgilio F, Borea PA, Illes P: P2 receptors meet the immune system Trends Pharmacol Sci 2001, 22(1):5-7.

37. Wang X, Arcuino G, Takano T, Lin J, Peng WG, Wan P, Li P, Xu Q, Liu QS, Goldman SA, Nedergaard M: P2X7 receptor inhibition improves recovery after spinal cord injury. Nat Med 2004, 10(8):821-827.

38. Lee DH, Park KS, Kong ID, Kim JW, Han BG: Expression of P2 receptors in human B cells and Epstein-Barr virus-transformed lymphoblastoid cell lines. BMC Immunol 2006, 7:22

39. Linden J: Regulation of Leukocyte Function by Adenosine Receptors. In Advances in Pharmacology. Volume 61. Edited by Kenneth AJ, Joel L. Kansas City: Academic Press; 2011:95-114.

40. Mei L, Du W, Gao W, Mei QB: Purinergic signaling: a novel mechanism in immune surveillance. Acta Pharmacol Sin 2010, 31(9):1149-1153.

41. Idzko M, Dichmann S, Ferrari D, Di Virgilio F, la Sala A, Girolomoni G, Panther E, Norgauer J: Nucleotides induce chemotaxis and actin polymerization in immature but not mature human dendritic cells via activation of pertussis toxin-sensitive $\mathrm{P} 2 \mathrm{y}$ receptors. Blood 2002, 100(3):925-932.

42. Linden J: Molecular approach to adenosine receptors: receptor-mediated mechanisms of tissue protection. Annu Rev Pharmacol Toxicol 2001 41:775-787.

43. Fredholm BB, ljzerman AP, Jacobson KA, Klotz KN, Linden J: International Union of Pharmacology. XXV. Nomenclature and classification of adenosine receptors. Pharmacol Rev 2001, 53(4):527-552.
44. Hasko G, Linden J, Cronstein B, Pacher P: Adenosine receptors: therapeutic aspects for inflammatory and immune diseases. Nat Rev Drug Discov 2008, 7(9):759-770

45. Thiel M, Chambers JD, Chouker A, Fischer S, Zourelidis C, Bardenheuer HJ, Peter K: Effect of adenosine on the expression of b2-integrins and I-selectin of polymorphonuclear leukocytes in vitro. J Leukocyte Biol 1996, 59:671-682.

46. Cronstein BN, Levin Rl, Philips M, Hirschhorn R, Abramson SB, Weissmann G: Neutrophil adherence to endothelium is enhanced via adenosine A1 receptors and inhibited via adenosine A2 receptors. J Immunol 1992, 148:2201-2206.

47. Cronstein BN, Rosenstein ED, Kramer SB, Weissmann G, Hirschhorn R: Adenosine: a physiologic modulator of superoxide anion generation by human neutrophils. Adenosine acts via an A2 receptor on human neutrophils. J Immunol 1985, 2:1366-1371.

48. Richter J: Effect of adenosine analogues and CAMP-raising agents on TNF-, GM-CSF-, and chemotactic peptide-induced degranulation in single adherent neutrophils. J Leukocyte Biol 1992, 51:270-275.

49. Thiel $M$, Chouker $A$ : Acting via $A 2$ receptors, adenosine inhibits the production of tumor necrosis factor-a of endotoxin-stimulated human polymorphonuclear leukocytes. J Lab Clin Med 1995, 124:275-282.

50. Cronstein BN, Daguma L, Nichols D, Hutchison AJ, Williams M: The adenosine/neutrophil paradox resolved: human neutrophils possess both $\mathrm{A} 1$ and $\mathrm{A} 2$ receptors that promote chemotaxis and inhibit O2-generation, respectively. J Clin Invest 1990, 85:1150-1157.

51. Broussas M, Cornillet-Lefèbvre P, Potron G, Nguyen P: Inhibition of fMLPtriggered respiratory burst of human monocytes by adenosine: involvement of A3 adenosine receptor. J Leukocyte Biol 1999, 66:495-501.

52. Sajjadi FG, Takabayashi K, Foster AC, Domingo RC, Firestein GS: Inhibition of TNF-alpha expression by adenosine: role of $\mathrm{A} 3$ adenosine receptors. J Immunol 1996, 156:3435-3442.

53. Elliott MR, Chekeni FB, Trampont PC, Lazarowski ER, Kadl A, Walk SF, Park D, Woodson RI, Ostankovich M, Sharma P, Lysiak JJ, Harden TK, Leitinger N, Ravichandran KS: Nucleotides released by apoptotic cells act as a find-me signal to promote phagocytic clearance. Nature 2009, 461(7261):282-286.

54. Chen Y, Corriden R, Inoue Y, Yip L, Hashiguchi N, Zinkernagel A, Nizet $V$, Insel PA, Junger WG: ATP release guides neutrophil chemotaxis via P2Y2 and A3 receptors. Science (New York, NY) 2006, 314(5806):1792-1795.

55. Kronlage M, Song J, Sorokin L, Isfort K, Schwerdtle T, Leipziger J, Robaye B, Conley PB, Kim HC, Sargin S, Schön P, Schwab A, Hanley PJ: Autocrine purinergic receptor signaling is essential for macrophage chemotaxis. Sci Signal 2010, 3(132):ra55-ra.

56. McDonald B, Pittman K, Menezes GB, Hirota SA, Slaba I, Waterhouse CC, Beck $\mathrm{PL}$, Muruve DA, Kubes P: Intravascular danger signals guide neutrophils to sites of sterile inflammation. Science 2010, 330(6002):362-366.

57. Honda S, Sasaki Y, Ohsawa K, Imai Y, Nakamura Y, Inoue K, Kohsaka S: Extracellular ATP or ADP induce chemotaxis of cultured microglia through Gi/o-coupled P2Y receptors. J Neurosci 2001, 21(6):1975-1982.

58. Chekeni FB, Elliott MR, Sandilos JK, Walk SF, Kinchen JM, Lazarowski ER, Armstrong AJ, Penuela S, Laird DW, Salvesen GS, Isakson BE, Bayliss DA Ravichandran KS: Pannexin 1 channels mediate 'find-me' signal release and membrane permeability during apoptosis. Nature 2010, 467(7317):863-867.

59. Sluyter R, Barden JA, Wiley JS: Detection of P2X purinergic receptors on human B lymphocytes. Cell Tissue Res 2001, 304(2):231-236.

60. Sakowicz-Burkiewicz M, Kocbuch K, Grden M, Szutowicz A, Pawelczyk T: Adenosine 5 '-triphosphate is the predominant source of peripheral adenosine in human B lymphoblasts. J Physiol Pharmacol 2010, 61(4):491-499

61. Padeh S, Cohen A, Roifman CM: ATP-induced activation of human B lymphocytes via P2-purinoceptors. J Immunol 1991, 146(5):1626-1632.

62. Baricordi OR, Melchiorri L, Adinolfi E, Falzoni S, Chiozzi P, Buell G, Di Virgilio $F$ : Increased proliferation rate of lymphoid cells transfected with the P2X7 ATP receptor. J Biol Chem 1999, 274:33206-33208.

63. Chvatchko Y, Valera S, Aubry JP, Renno T, Buell G, Bonnefoy JY: The involvement of an ATP-gated ion channel, $\mathrm{P}(2 \mathrm{X} 1)$, in thymocyte apoptosis. Immunity 1996, 5(3):275-283.

64. Apasov SG, Koshiba M, Chused TM, Sitkovsky MV: Effects of extracellular ATP and adenosine on different thymocyte subsets: possible role of 
ATP-gated channels and G protein-coupled purinergic receptor. J Immunol 1997, 158(11):5095-5105.

65. Freedman BD, Liu QH, Gaulton G, Kotlikoff MI, Hescheler J, Fleischmann BK: ATP-evoked $\mathrm{Ca} 2+$ transients and currents in murine thymocytes: possible role for P2X receptors in death by neglect. Eur J Immunol 1999, 29(5):1635-1646.

66. Nagy PV, Feher T, Morga S, Matko J: Apoptosis of murine thymocytes induced by extracellular ATP is dose- and cytosolic $\mathrm{pH}$-dependent. Immunol Lett 2000, 72(1):23-30

67. Auger R, Motta I, Benihoud K, Ojcius DM, Kanellopoulos JM: A role for mitogen-activated protein kinase(Erk1/2) activation and non-selective pore formation in P2X7 receptor-mediated thymocyte death. J Biol Chem 2005, 280(30):28142-28151.

68. Lépine S, Le Stunff H, Lakatos B, Sulpice JC, Giraud F: ATP-induced apoptosis of thymocytes is mediated by activation of P2X7 receptor and involves de novo ceramide synthesis and mitochondria. Biochim Biophys Acta 2006, 1761(1):73-82

69. Tsukimoto M, Maehata M, Harada H, Ikari A, Takagi K, Degawa M: P2X7 receptordependent cell death is modulated during murine $\mathrm{T}$ cell maturation and mediated by dual signaling pathways. J Immunol 2006, 177(5):2842-2850.

70. Ross PE, Ehring GR, Cahalan MD: Dynamics of ATP-induced calcium signaling in single mouse thymocytes. J Cell Biol 1997, 138(5):987-998.

71. Frascoli M, Marcandalli J, Schenk U, Grassi F: Purinergic P2X7 receptor drives $\mathrm{T}$ cell lineage choice and shapes peripheral gammadelta cells. J Immunol 2012, 189(1):174-180.

72. Loomis WH, Namiki S, Ostrom RS, Insel PA: Hypertonic stress increases T cells interleukin-2 expression through a mechanism that involves ATP release, P2 receptor, and p38 MAPK activation. J Biol Chem 2003, 278:4590-4596.

73. Yip L, Cheung CW, Corriden R, Chen Y, Insel PA, Junger WG: Hypertonic stress regulates T-cell function by the opposing actions of extracellular adenosine triphosphate and adenosine. Shock 2007, 27(3):242-250.

74. Corriden R, Insel PA, Junger WG: A novel method using fluorescence microscopy for real-time assessment of ATP release from individual cells. Am J Physiol Cell Physiol 2007, 293(4):C1420-C1425.

75. Yip L, Woehrle T, Corriden R, Hirsh M, Chen Y, Inoue Y, Ferrari V, Insel PA, Junger WG: Autocrine regulation of T-cell activation by ATP release and P2X7 receptors. FASEB J 2009, 23(6):1685-1693.

76. Woehrle T, Yip L, Manohar M, Sumi Y, Yao Y, Chen Y, Junger WG: Hypertonic stress regulates $T$ cell function via pannexin-1 hemichannels and P2X receptors. J Leukoc Biol 2010, 88(6):1181-1189.

77. Woehrle T, Yip L, Elkhal A, Sumi Y, Chen Y, Yao Y, Insel PA, Junger WG: Pannexin-1 hemichannel-mediated ATP release together with $\mathrm{P} 2 \mathrm{X} 1$ and $\mathrm{P} 2 \mathrm{X} 4$ receptors regulate $\mathrm{T}-$ cell activation at the immune synapse. Blood 2010, 116(18):3475-3484

78. Schenk U, Westendorf AM, Radaelli E, Casati A, Ferro M, Fumagalli M, Verderio C, Buer J, Scanziani E, Grassi F: Purinergic control of T cell activation by ATP released through pannexin-1 hemichannels. Sci Signal 2008, 1(39):ra6,

79. Tokunaga A, Tsukimoto M, Harada H, Moriyama Y, Kojima S: Involvement of SLC17A9-dependent vesicular exocytosis in the mechanism of ATP release during T cell activation. J Biol Chem 2010, 285(23):17406-17416.

80. Baricordi OR, Ferrari D, Melchiorri L, Chiozzi P, Hanau S, Chiari E, Rubini M, Di Virgilio F: An ATP-activated channel is involved in mitogenic stimulation of human T lymphocytes. Blood 1996, 87(2):682-690.

81. Filippini A, Taffs RE, Sitkovsky MV: Extracellular ATP in T-lymphocyte activation: possible role in effector functions. Proc Natl Acad Sci U S A 1990, 87(21):8267-8271.

82. Langston HP, Ke Y, Gewirtz AT, Dombrowski KE, Kapp JA: Secretion of IL-2 and IFN-gamma, but not IL-4, by antigen-specific T cells requires extracellular ATP. J Immunol 2003, 170(6):2962-2970.

83. Manohar M, Hirsh MI, Chen Y, Woehrle T, Karande AA, Junger WG: ATP release and autocrine signaling through $\mathrm{P} 2 \mathrm{X} 4$ receptors regulate $\gamma \delta \mathrm{T}$ cell activation. J Leukoc Biol 2012, 92(4):787-794.

84. Schenk U, Frascoli M, Proietti M, Geffers R, Traggiai E, Buer J, Ricordi C, Westendorf AM, Grassi F: ATP inhibits the generation and function of regulatory $\mathrm{T}$ cells through the activation of purinergic $\mathrm{P} 2 \mathrm{X}$ receptors. Sci Signal 2011, 4(162):ra12.

85. Ferrari D, Pizzirani C, Adinolfi E, Lemoli RM, Curti A, Idzko M, Panther E, Di Virgilio F: The P2X7 receptor: a key player in IL-1 processing and release. $J$ Immunol 2006, 176(7):3877-3883.
86. Volonte C, Apolloni S, Skaper SD, Burnstock G: P2X7 receptors: channels, pores and more. CNS Neurol Disord Drug Targets 2012, 11(6):705-721.

87. Netea MG, Simon A, van de Veerdonk F, Kullberg BJ, Van der Meer JW, Joosten LA: IL-1 beta processing in host defense: beyond the inflammasomes. PLoS Pathog 2010, 6(2):e1000661.

88. Trautmann A: Extracellular ATP in the immune system: more than just a "danger signal". Sci Signal 2009, 2(56):pe6-pe.

89. Zimmermann $\mathrm{H}$, Zebisch M, Strater N: Cellular function and molecular structure of ecto-nucleotidases. Purinergic Signal 2012, 8(3):437-502.

90. Idzko M, Ferrari D, Eltzschig HK: Nucleotide signalling during inflammation. Nature 2014, 509(7500):310-317.

91. Gorini S, Gatta L, Pontecorvo L, Vitiello L, la Sala A: Regulation of innate immunity by extracellular nucleotides. Am J Blood Res 2013, 3(1):14-28.

92. Corriden R, Insel PA: Basal release of ATP: an autocrine-paracrine mechanism for cell regulation. Sci Signal 2010, 3(104):re1.

93. Di Virgilio F: Purinergic signalling in the immune system. A brief update. Purinergic Signal 2007, 3(1-2):1-3.

94. Rossi L, Salvestrini V, Ferrari D, Di Virgilio F, Lemoli RM: The sixth sense: hematopoietic stem cells detect danger through purinergic signaling. Blood 2012, 120(12):2365-2375.

95. Dubyak GR: P2X7 receptor regulation of non-classical secretion from immune effector cells. Cell Microbiol 2012, 14(11):1697-1706.

96. Miller CM, Boulter NR, Fuller SJ, Zakrzewski AM, Lees MP, Saunders BM, Wiley JS, Smith NC: The role of the P2X(7) receptor in infectious diseases. PLoS Pathog 2011, 7(11):e1002212.

97. Molloy A, Laochumroonvorapong P, Kaplan G: Apoptosis, but not necrosis, of infected monocytes is copled with killing of intracellular bacillus Calmette-Guerin. J exp Med 1994, 180(4):1499-1509.

98. Lammas DA, Stober C, Harvey CJ, Kendrick N, Panchalingam S, Kumararatne DS: ATP-induced killing of mycobacteria by human macrophages is mediated by purinergic P2Z(P2X7) receptors. Immunity 1997, 7(3):433-444.

99. Kusner DJ, Barton JA: ATP stimulates human macrophages to kill intracellular virulent Mycobacterium tuberculosis via calcium-dependent phagosome-lysosome fusion. J Immunol 2001, 167(6):3308-3315.

100. Stober CB, Lammas DA, Li CM, Kumararatne DS, Lightman SL, McArdle CA: ATP-mediated killing of Mycobacterium bovis bacille Calmette-Guérin within human macrophages is calcium dependent and associated with the acidification of mycobacteria-containing phagosomes. J Immunol 2001, 166(10):6276-6286

101. Smith RA, Alvarez AJ, Estes DM: The P2X7 purinergic receptor on bovine macrophages mediates mycobacterial death. Vet Immunol Immunopathol 2001, 78(3-4):249-262.

102. Fairbairn IP, Stober CB, Kumararatne DS, Lammas DA: ATP-mediated killing of intracellular mycobacteria by macrophages is a P2X(7)-dependent process inducing bacterial death by phagosome-lysosome fusion. $J$ Immunol 2001, 167(6):3300-3307.

103. Saunders BM, Fernando SL, Sluyter R, Britton WJ, Wiley JS: A loss-offunction polymorphism in the human $\mathrm{P} 2 \mathrm{X} 7$ receptor abolishes ATP-mediated killing of mycobacteria. J Immunol 2003, 171(10):5442-5446.

104. Fernando SL, Saunders BM, Sluyter R, Skarratt KK, Goldberg H, Marks GB, Wiley JS, Britton WJ: A polymorphism in the P2X7 gene increases susceptibility to extrapulmonary tuberculosis. AmJ RespirCrit Care Med 2007, 175(4):360-366.

105. Shemon AN, Sluyter R, Fernando SL, Clarke AL, Dao-Ung LP, Skarratt KK, Saunders BM, Tan KS, Gu BJ, Fuller SJ, Britton WJ, Petrou S, Wiley JS: A Thr357 to Ser polymorphism in homozygous and compound heterozygous subjects causes absent or reduced P2X7 function and impairs ATP-induced mycobacterial killing by macrophages. J Biol Chem 2006, 281(4):2079-2086

106. Franco-Martínez S, Niño-Moreno P, Bernal-Silva S, Baranda L, Rocha-Meza M, Portales-Cervantes L, Layseca-Espinosa E, González-Amaro R, Portales-Pérez $D$ : Expression and function of the purinergic receptor $P 2 X 7$ in patients with pulmonary tuberculosis. Clin Exp Immunol 2006, 146(2):253-261.

107. Placido R, Auricchio G, Falzoni S, Battistini L, Colizzi V, Brunetti E, Di Virgilio F, Mancino G: P2X(7) purinergic receptors and extracellular ATP mediate apoptosis of human monocytes/macrophages infected with Mycobacterium tuberculosis reducing the intracellular bacterial viability. Cellular immunology 2006, 244(1):10-18.

108. Biswas D, Qureshi OS, Lee WY, Croudace JE, Mura M, Lammas DA: ATP-induced autophagy is associated with rapid killing of intracellular 
mycobacteria within human monocytes/macrophages. BMC Immunol 2008, 9:35.

109. Coutinho-Silva R, Perfettini JL, Persechini PM, Dautry-Varsat A, Ojcius DM: Modulation of $\mathrm{P} 2 \mathrm{Z} / \mathrm{P} 2 \mathrm{X}(7)$ receptor activity in macrophages infected with Chlamydia psittaci. Am J Physiol Cell Physiol 2001, 280(1):C81-9.

110. Coutinho-Silva R, Stahl L, Raymond MN, Jungas T, Verbeke P, Burnstock G, Darville T, Ojcius DM: Inhibition of chlamydial infectious activity due to P2X7R-dependent phospholipase D activation. Immunity 2003, 19(3):403-412.

111. Darville T, Welter-Stahl L, Cruz C, Sater AA, Andrews CW Jr, Ojcius DM: Effect of the purinergic receptor P2X7 on Chlamydia infection in cervical epithelial cells and vaginally infected mice. J Immunol 2007, 179(6):3707-3714

112. Kolli BK, Kostal J, Zaborina O, Chakrabarty AM, Chang K: Leishmaniareleased nucleoside diphosphate kinase prevents ATP-mediated cytolysis of macrophages. Mol Biochem Parasitol 2008, 158(2):163-175.

113. Chaves SP, Torres-Santos EC, Marques C, Figliuolo VR, Persechini PM, Coutinho-Silva R, Rossi-Bergmann B: Modulation of P2X(7) purinergic receptor in macrophages by Leishmania amazonensis and its role in parasite elimination. Microbes Infect 2009, 11(10-11):842-849.

114. Marques-da-Silva C, Chaves MM, Rodrigues JC, Corte-Real S, Coutinho-Silva R, Persechini PM: Differential modulation of ATP-induced P2X7-associated permeabilities to cations and anions of macrophages by infection with Leishmania amazonensis. PLoS One 2011, 6(9):e25356.

115. Marques-da-Silva C, Chaves MM, Chaves SP, Figliuolo VR, Meyer-Fernandes JR, Corte-Real S, Lameu C, Ulrich H, Ojcius DM, Rossi-Bergmann B, Coutinho-Silva R: Infection with Leishmania amazonensis upregulates purinergic receptor expression and induces host-cell susceptibility to UTP-mediated apoptosis. Cell Microbiol 2011, 13(9):1410-1428.

116. Correa G, Marques da Silva C, de Abreu Moreira-Souza AC, Vommaro RC, Coutinho-Silva R: Activation of the $\mathrm{P} 2 \mathrm{X}(7)$ receptor triggers the elimination of Toxoplasma gondii tachyzoites from infected macrophages. Microbes Infect 2010, 12(6):497-504.

117. Lees MP, Fuller SJ, McLeod R, Boulter NR, Miller CM, Zakrzewski AM, Mui EJ, Witola WH, Coyne JJ, Hargrave AC, Jamieson SE, Blackwell JM, Wiley JS, Smith NC: P2X7 receptor-mediated killing of an intracellular parasite, Toxoplasma gondii, by human and murine macrophages. J Immunol 2010, 184(12):7040-7046.

118. Jamieson SE, Peixoto-Rangel AL, Hargrave AC, Roubaix LA, Mui EJ, Boulter NR, Miller EN, Fuller SJ, Wiley JS, Castellucci L, Boyer K, Peixe RG, Kirisits MJ, Elias Lde S, Coyne JJ, Correa-Oliveira R, Sautter M, Smith NC, Lees MP, Swisher CN, Heydemann P, Noble AG, Patel D, Bardo D, Burrowes D, McLone D, Roizen N, Withers S, Bahia-Oliveira LM, McLeod R, et al: Evidence for associations between the purinergic receptor P2X(7) (P2RX7) and toxoplasmosis. Genes Immun 2010, 11(5):374-383.

119. Miller CM, Zakrzewski AM, Ikin RJ, Boulter NR, Katrib M, Lees MP, Fuller SJ, Wiley JS, Smith NC: Dysregulation of the inflammatory response to the

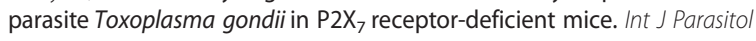
2011, 41(3-4):301-308.

120. Petcu DJ, Aldrich CE, Coates L, Taylor JM, Mason WS: Suramin inhibits in vitro infection by duck hepatitis B virus, Rous sarcoma virus, and hepatitis delta virus. Virology 1988, 167(2):385-392.

121. Schulze A, Gripon P, Urban S: Hepatitis B virus infection initiates with a large surface protein-dependent binding to heparan sulfate proteoglycans. Hepatology 2007, 46(6):1759-1768.

122. Taylor JM, Han Z: Purinergic receptor functionality is necessary for infection of human hepatocytes by hepatitis delta virus and hepatitis $B$ virus. PLoS One 2010, 5(12):e15784.

123. Croon JJ, Wolff HL: The inhibition of yellow fever virus multiplication by suramin: a preliminary note. Acta Leiden 1982, 48:5-8.

124. Xu K, Ren H, Zhu J, Yang Y, Liao F: Suramin inhibits the in vitro expression of encephalitis B virus proteins NS3 and E. J Huazhong Univ Sci Technolog Med Sci 2003, 23(4):375-379.

125. Zandberg M, van Son WJ, Harmsen MC, Bakker WW: Infection of human endothelium in vitro by cytomegalovirus causes enhanced expression of purinergic receptors: a potential virus escape mechanism? Transplantation 2007, 84(10):1343-1347.

126. Levy JA: Pathogenesis of human immunodeficiency virus infection. Microbiol Rev 1993, 57(1):183-289.

127. Piatak M Jr, Saag MS, Yang LC, Clark SJ, Kappes JC, Luk KC, Hahn BH, Shaw GM, Lifson JD: High levels of HIV-1 in plasma during all stages of infection determined by competitive PCR. Science 1993, 259(5102):1749-1754.

128. Fauci AS: Host factors and the pathogenesis of HIV-induced disease. Nature 1996, 384(6609):529-534.

129. Freed EO: HIV-1 replication. Somat Cell Mol Genet 2001, 26(1-6):13-33.

130. Costin JM: Cytopathic mechanisms of HIV-1. Virol J 2007, 4:100.

131. Lieberman J, Shankar P, Manjunath N, Andersson J: Dressed to kill? A review of why antiviral CD8 $\mathrm{T}$ lymphocytes fail to prevent progressive immunodeficiency in HIV-1 infection. Blood 2001, 98(6):1667-1677.

132. Peretz Y, Cameron C, Sekaly RP: Dissecting the HIV-specific immune response: a systems biology approach. Curr Opin HIV AIDS 2012, 7(1):17-23.

133. Ries M, Pritschet K, Schmidt B: Blocking type I interferon production: a new therapeutic option to reduce the HIV-1-induced immune activation. Clin Dev Immunol 2012, 2012:534929.

134. Benecke A, Gale M Jr, Katze MG: Dynamics of innate immunity are key to chronic immune activation in AIDS. Curr Opin HIV AIDS 2012, 7(1):79-85.

135. Lassen K, Han Y, Zhou Y, Siliciano J, Siliciano RF: The multifactorial nature of HIV-1 latency. Trends Mol Med 2004, 10(11):525-531.

136. Autran B, Carcelain G, Li TS, Blanc C, Mathez D, Tubiana R, Katlama C, Debré $P$, Leibowitch J: Positive effects of combined antiretroviral therapy on CD4+ T cell homeostasis and function in advanced HIV disease. Science 1997, 277(5322):112-116

137. Cohen OJ, Fauci AS: Benchmarks for antiretroviral therapy. J Clin Invest 2000, 105(6):709-710.

138. Bailey J, Blankson JN, Wind-Rotolo M, Siliciano RF: Mechanisms of HIV-1 escape from immune responses and antiretroviral drugs. Curr Opin Immunol 2004, 16(4):470-476.

139. Corbeau $P$, Reynes J: Immune reconstitution under antiretroviral therapy: the new challenge in HIV-1 infection. Blood 2011, 117(21):5582-5590.

140. Sension MG: Long-Term suppression of HIV infection: benefits and limitations of current treatment options. J Assoc Nurses AIDS Care 2007, 18(1 Suppl):S2-S10.

141. De Clercq E: New developments in anti-HIV chemotherapy. Biochim Biophys Acta 2002, 1587(2-3):258-275.

142. Simon V, Vanderhoeven J, Hurley A, Ramratnam B, Louie M, Dawson K, Parkin N, Boden D, Markowitz M: Evolving patterns of HIV-1 resistance to antiretroviral agents in newly infected individuals. AIDS 2002, 16(11):1511-1519.

143. Jiang $Y$, Liu $X$, De Clerca E: New therapeutic approaches targeted at the late stages of the HIV-1 replication cycle. Curr Med Chem 2011, 18(1):16-28.

144. Seror C, Melki MT, Subra F, Raza SQ, Bras M, Saidi H, Nardacci R, Voisin L, Paoletti A, Law F, Martins I, Amendola A, Abdul-Sater AA, Ciccosanti F, Delelis O, Niedergang F, Thierry S, Said-Sadier N, Lamaze C, Métivier D, Estaquier J, Fimia GM, Falasca L, Casetti R, Modjtahedi N, Kanellopoulos J, Mouscadet JF, Ojcius DM, Piacentini M, Gougeon ML, et al: Extracellular ATP acts on P2Y2 purinergic receptors to facilitate HIV-1 infection. J Exp Med 2011, 208(9):1823-1834.

145. Schuitemaker H, Kootstra NA, de Goede RE, de Wolf F, Miedema F, Tersmette M: Monocytotropic human immunodeficiency virus type 1 (HIV-1) variants detectable in all stages of HIV-1 infection lack T-cell line tropism and syncytium-inducing ability in primary T-cell culture. J Virol 1991, 65(1):356-363.

146. Coiras M, Lopez-Huertas MR, Perez-Olmeda M, Alcami J: Understanding HIV-1 latency provides clues for the eradication of long-term reservoirs. Nat Rev Microbiol 2009, 7(11):798-812.

147. Duncan CJ, Sattentau QJ: Viral determinants of HIV-1 macrophage tropism. Viruses 2011, 3(11):2255-2279.

148. Hazleton JE, Berman JW, Eugenin EA: Purinergic receptors are required for HIV-1 infection of primary human macrophages. J Immunol 2012, 188(9):4488-4495.

149. Swartz TH, Esposito AM, Durham ND, Hartmann BM, Chen BK: P2X-Selective Purinergic Antagonists Are Strong Inhibitors of HIV-1 Fusion during both Cell-to-Cell and Cell-Free Infection. J Virol 2014, 88(19):11504-11515.

150. Tovar-Y-Romo LB, Kolson DL, Bandaru W, Drewes JL, Graham DR, Haughey $\mathrm{NJ}$ : Adenosine triphosphate released from HIV-infected macrophages regulates glutamatergic tone and dendritic spine density on neurons. J Neuroimmune Pharmacol 2013, 8:998-1009.

151. Sorrell ME, Hauser KF: Ligand-gated purinergic receptors regulate HIV-1 Tat and morphine related neurotoxicity in primary mouse 
striatal neuron-glia co-cultures. J Neuroimmune Pharmacol 2014, 9(2):233-244.

152. Pingle SC, Jajoo S, Mukherjea D, Sniderhan LF, Jhaveri KA, Marcuzzi A, Rybak $L P$, Maggirwar SB, Ramkumar V: Activation of the adenosine A1 receptor inhibits HIV-1 tat-induced apoptosis by reducing nuclear factor-kappaB activation and inducible nitric-oxide synthase. Mol Pharmacol 2007, 72(4):856-867.

153. Fotheringham J, Mayne M, Holden C, Nath A, Geiger JD: Adenosine receptors control HIV-1 Tat-induced inflammatory responses through protein phosphatase. Virology 2004, 327(2):186-195.

154. Kumar V, Sharma A: Adenosine: an endogenous modulator of innate immune system with therapeutic potential. Eur J Pharmacol 2009, 616(1-3):7-15

155. By Y, Durand-Gorde JM, Condo J, Lejeune PJ, Fenouillet E, Guieu R, Ruf J: Monoclonal antibody-assisted stimulation of adenosine A2A receptors induces simultaneous downregulation of CXCR4 and CCR5 on CD4+ T-cells. Hum Immunol 2010, 71(11):1073-1076.

156. Prevelige PE Jr: New approaches for antiviral targeting of HIV assembly. J Mol Biol 2011, 410(4):634-640.

157. Hayes MM, Lane BR, King SR, Markovitz DM, Coffey MJ: Prostaglandin E(2) inhibits replication of HIV-1 in macrophages through activation of protein kinase A. Cell Immunol 2002, 215(1):61-71.

158. Barbera-Cremades M, Baroja-Mazo A, Gomez Al, Machado F, Di Virgilio F, Pelegrin P: P2X7 receptor-stimulation causes fever via PGE2 and IL-1 beta release. FASEB J 2012, 26(7):2951-2962.

159. Leal DB, Streher CA, Bertoncheli Cde M, Carli LF, Leal CA, da Silva JE, Morsch VM, Schetinger MR: HIV infection is associated with increased NTPDase activity that correlates with CD39-positive lymphocytes. Biochim Biophys Acta 2005, 1746(2):129-134

doi:10.1186/1745-6150-9-21

Cite this article as: Pacheco et al:: Putative roles of purinergic signaling in human immunodeficiency virus-1 infection. Biology Direct 2014 9:21.

\section{Submit your next manuscript to BioMed Central and take full advantage of:}

- Convenient online submission

- Thorough peer review

- No space constraints or color figure charges

- Immediate publication on acceptance

- Inclusion in PubMed, CAS, Scopus and Google Scholar

- Research which is freely available for redistribution

Submit your manuscript at www.biomedcentral.com/submit
() Biomed Central 